\title{
Electrochromic Thin Films Based on NiAl Layered Double Hydroxide Nanoclusters for Smart Windows and Low-Power Displays
}

Paulmanickam Koilraj, Masanori Takemoto, Yasuaki Tokudome, Angelique Bousquet, Vanessa Prevot,* and Christine Mousty*

Cite This: ACS Appl. Nano Mater. 2020, 3, 6552-6562

Read Online

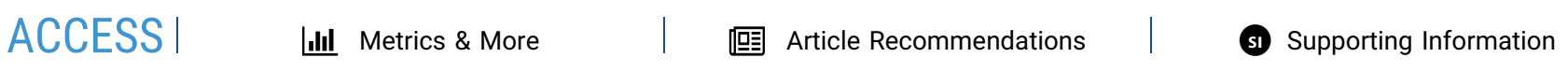
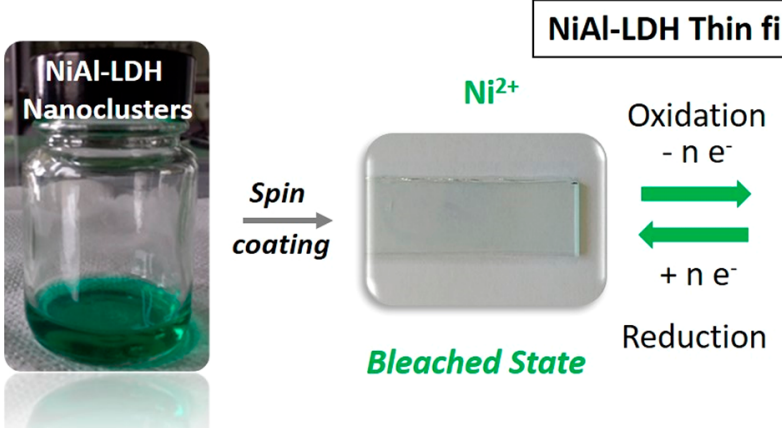

Bleached State

Reduction

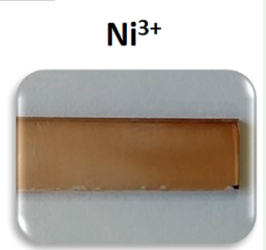

Colored State

ABSTRACT: To develop electrochromic thin films for smart windows and low-power displays, homogeneous thin films were produced by spin coating colloidal NiAl layered double hydroxide (LDH) nanocluster solutions on a fluorine-doped tin oxide (FTO) glass substrate. The nano-LDH dispersion was synthesized via a facile one-step epoxide mediated process at room temperature. In situ relative transmittance measurements at $400 \mathrm{~nm}$, recorded during potential scans in cyclic voltammetry or differential pulse chronoamperometry, showed the electrochromic behavior of the homogeneous thin films. The impact of various parameters on the electrochromic properties of the films was detailed, such as the thickness of the film, the nature of the electrolyte, and the presence of electroactive anions. The electrochromic properties, namely, the change in transmittance $(\Delta T)$ and the bleaching reversibility, were greatly improved using alkaline metal hydroxide as the electrolyte and in the presence of $\mathrm{Fe}(\mathrm{CN})_{6}{ }^{4-}$. The performances that we reached from the deposition of nanoclusters can be advantageously compared to the literature with $\Delta T=$ $70 \%$ and fast and good reversibility. Upon calcination, the NiAl-LDH film converted into mixed oxides $\left(\mathrm{NiO}\right.$ and $\left.\mathrm{NiAl} \mathrm{O}_{4}\right)$. The higher the calcination temperature, the lower was the $\Delta T$ value. The presence of porosity within the thin films, through the introduction of sacrificial polymeric beads and then decomposition at $400{ }^{\circ} \mathrm{C}$, was investigated, highlighting an enhancement of the $\Delta T$ value attributed to better accessibility to the nickel redox sites.

KEYWORDS: electrochromism, layered double hydroxides, thin films, nanoclusters, ferrocyanide

\section{INTRODUCTION}

Electrochromism ${ }^{1}$ relates to a reversible change of the optical properties of a material induced by an external applied potential. Electrochromic (EC) materials have shown great interest in electrochromic device development for potential applications in the smart window, low-power display, antiglare rearview mirror, and so on..$^{2}$ Among the different electroactive species described for electrochromism, such as metal oxides $\left.\left(\mathrm{WO}_{3}, \mathrm{IrO}_{2}, \mathrm{MoO}_{3}, \mathrm{Nb}_{2} \mathrm{O}_{5}, \mathrm{NiO}\right)\right)^{3,4}$ hexacyanometallates, viologens, ${ }^{5}$ conjugated polymers (polyaniline, polypyrrole, and poly (3,4-ethylenedioxythiophene)/poly(styrenesulfonate) (PEDOT:PSS)), ${ }^{6}$ and hybrid materials, ${ }^{7}$ layered double hydroxides $(\mathrm{LDH})$, displaying versatile chemical composition, were also reported as potential candidates in designing electrochromic devices. The structure of $\mathrm{LDH}$ is related to that of brucite, $\mathrm{M}^{\mathrm{II}}(\mathrm{OH})_{2}$, in which some of the $\mathrm{M}^{2+}$ cations were replaced by trivalent cations and intercalated anions between the layers maintain the electroneutrality. ${ }^{8}$ Their layered structure, wide chemical compositions due to a variable isomorphous substitution of metal cations, variable layer charge density, ion-exchange properties, reactive interlayer space, and rheological and colloidal properties made $\mathrm{LDH}$ and hybrid $\mathrm{LDH}^{9}$ interesting inorganic matrices

Received: April 17, 2020

Accepted: June 15, 2020

Published: June 15, 2020 
Scheme 1. Schematic Illustration of the Research Carried out in This Work from the NiAl-LDH ${ }_{\mathrm{NC}}$ Thin Film Preparation to the Study of Their Electrochromic Properties

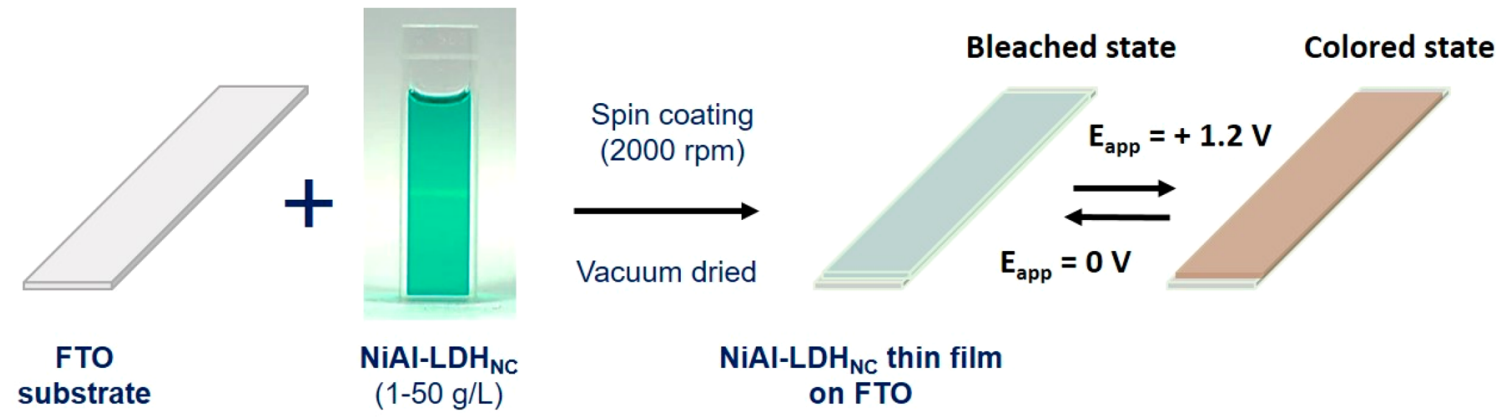

in various applied fields such as environmental remediation, ${ }^{10,11}$ catalysis (photo, electro, and bio), ${ }^{12-17}$ biomedical applications, ${ }^{18,19}$ energy storage/conversion systems, ${ }^{20,21}$ and polymer nanocomposites. $^{22-24}$

In the field of electrochromism, the benefit of $\mathrm{LDH}$ materials has been demonstrated through different strategies. Electrochromic films were fabricated from positively charged LDH exfoliated nanosheets and anionic electrochromic species such as Prussian Blue $\mathrm{KFe}^{\mathrm{III}}\left[\mathrm{Fe}^{\mathrm{II}}(\mathrm{CN})_{6}\right]$, PEDOT:PSS through a layer by layer approach. ${ }^{25,26}$ Systematically, the electrochromic properties were enhanced by the presence of twodimensional $\mathrm{LDH}$ nanosheets in the thin films, leading to periodic long-range structures and homogeneous morphologies. Such superior performances were ascribed to an optimal distribution of the electrochromic species within the ordered film structure, which favored the ion diffusion and facilitated availability to active sites. In the same way, spiropyran, which is a neutral molecule, was also involved in the preparation of a switchable bifunctional (electrochromism and electroluminescence) ultrathin film. ${ }^{27}$ To promote the layer-by-layer assembly based on electrostatic interactions, ${ }^{28}$ negatively charged micelles of an amphiphilic block copolymer were used to encapsulate the spriopyran. The fabrication of photochromic films following the same layer-by-layer strategy involving CoAlLDH nanosheets and poly(vinyl alcohol) modified decatungstate was also reported by Wang et al. ${ }^{29}$

In parallel, intrinsic EC properties of $\mathrm{LDH}$ matrices were also investigated by Villemure's group. ${ }^{31-34}$ As observed for $\mathrm{NiO}$ and $\mathrm{Ni}(\mathrm{OH})_{2}$, in $\mathrm{NiAl}-\mathrm{LDH}$, the electrochemical oxidation of $\mathrm{Ni}$ sites in the layers is accompanied by a color change from clear to brown, which confers an EC behavior to this LDH. ${ }^{32-34}$ However, the main limitations for the use of NiAl-LDH matrices in electrochromic devices are related to the low electrochemical accessibility of the $\mathrm{Ni}$ sites in the layer and the limited reversibility of the EC process, which induce a moderate contrast between the bleached and colored states and slow bleaching of the films. Interestingly, the addition of electroactive ions, such as $\left[\mathrm{Co}(\mathrm{bpy})_{3}\right]^{2+},\left[\mathrm{Ru}(\mathrm{bpy})_{3}\right]^{2+}$, $\left[\mathrm{Fe}(\mathrm{CN})_{6}\right]^{4-}$, and $\left[\mathrm{Ru}(\mathrm{CN})_{6}\right]^{4-}$, in the electrolyte acting as electron mediators in the electrochemical oxidation and reduction of the $\mathrm{Ni}$ sites, is effective in improving the bleaching rate and the contrast of the film during the redox process. ${ }^{32}$ Further research is still required to obtain desirable homogeneous and transparent thin films of NiAl-LDH with improved accessibility of $\mathrm{Ni}$ sites and suitable EC properties. In the literature, it is reported that many parameters can be adjusted and tailored to improve the EC properties of inorganic materials ${ }^{1,2}$ and particularly the morphology and the structure of the electrochromic particles. These latter are usually related to the synthesis method and parameters used such as the nature of the precursors, the precipitant agent, the $\mathrm{pH}$, the supersaturation level, and the temperature. It is noteworthy that a variety of approaches can be used to prepare $\mathrm{LDH}^{35}$ such as direct coprecipitation, the urea method, the polyol method, and hydro- and solvothermal treatments, which in certain cases can tune the performances in the materials. For instance, in the case of NiAl-LDH synthesized by a glycineassisted hydrothermal method, ${ }^{35} 3 \mathrm{R}_{1}-2 \mathrm{H}_{1}$ intergrowth, which corresponds to the introduction of the $2 \mathrm{H}_{1}$ stacking order into the $3 \mathrm{R}_{1} \mathrm{LDH}$ structure, was evidenced, resulting in a net increase of the accessibility to the $\mathrm{Ni}$ site, enhancing the electrochemical response. ${ }^{36}$ Unfortunately, in this latter case, the particle size of around $200 \mathrm{~nm}$ is not favorable to the formation of homogeneous and transparent thin films.

In the present study, a novel scheme is proposed to construct an LDH-based EC system to achieve tunable homogeneous films with controllable structural properties and high optical transparency starting from the colloidal dispersion of NiAl-LDH nanoclusters (Scheme 1). ${ }^{37}$ By optimizing the film thickness, the electrolyte, and the presence of a redox mediator, we reached a nano-LDH-based EC system showing excellent performance compared to the literature. Since $\mathrm{NiO}$ is also described as a promising candidate in electrochromism, the films of derived $\mathrm{NiAl}-\mathrm{LDH}_{\mathrm{NC}}$ oxide and mixed oxides, obtained after calcination, were also investigated for comparison, with special attention to the effect of temperature of the thermal treatment and the film porosity.

\section{EXPERIMENTAL METHODS}

2.1. Synthesis of NiAl-LDH Nanoclusters by the Epoxide Method. The synthesis of NiAl-LDH nanoclusters $\left(\mathrm{NiAl}^{-} \mathrm{LDH}_{\mathrm{NC}}\right)$ was performed as recently reported. ${ }^{37}$ In brief, $\mathrm{NiCl}_{2} \cdot 6 \mathrm{H}_{2} \mathrm{O}(0.594 \mathrm{~g}$; $2.50 \mathrm{mmol})$ and $\mathrm{AlCl}_{3} \cdot 6 \mathrm{H}_{2} \mathrm{O}(0.302 \mathrm{~g} ; 1.25 \mathrm{mmol})$ were dissolved in a mixed solvent containing ethanol $(1.5 \mathrm{~mL} ; 25.7 \mathrm{mmol})$, water $(1.0$ $\mathrm{mL} ; 55.6 \mathrm{mmol})$, and acetyl acetone $(130 \mu \mathrm{L} ; 1.25 \mathrm{mmol})$. The mixture was stirred magnetically for $30 \mathrm{~min}$ at $20{ }^{\circ} \mathrm{C}$ in a closed container. Then, $1.31 \mathrm{~mL}$ of propylene oxide was added and stirred for $1 \mathrm{~min}$ to homogenize the sol and stored at $20{ }^{\circ} \mathrm{C}$ in a closed container for further use. The green sol became a gel after $2 \mathrm{~h}$ and went back to its original sol state after $24 \mathrm{~h}$.

2.2. Thin Film Preparation. Fluorine doped tin oxide (FTO) glass substrates coated with dilute suspensions of NiAl- $\mathrm{LDH}_{\mathrm{NC}}$ were prepared to conduct the electrochromic studies. The FTO glass substrates (SOLEMS 80/1.1; $1.5 \times 6 \mathrm{~cm}$ ) were cleaned in water and then in ethanol for $15 \mathrm{~min}$ under sonication before coating. The LDH suspension was diluted to obtain $1-50 \mathrm{~g} / \mathrm{L} \mathrm{NiAl}-\mathrm{LDH}_{\mathrm{NC}}$ in either ethanol or an ethanol/water mixture (0.38:0.62). $200 \mu \mathrm{L}$ of NiAl$\mathrm{LDH}_{\mathrm{NC}}$ suspension was spin-coated (WS-400/500B Lite Series Spin 

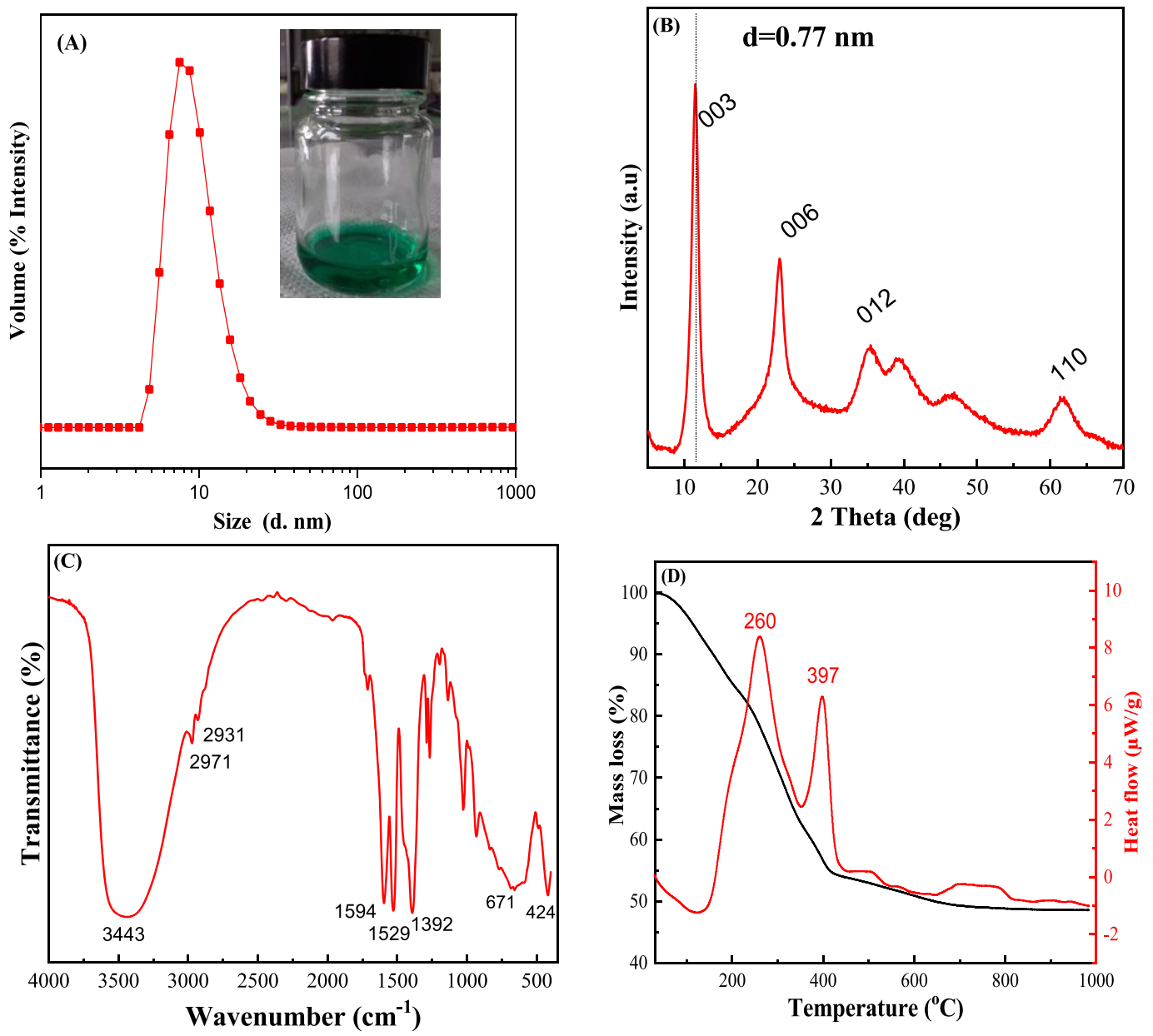

Figure 1. (A) Dynamic light scattering particle size (inset: digital photograph of the as-prepared suspension), (B) PXRD pattern, (C) FTIR spectrum, and (D) TG analysis of NiAl- $\mathrm{LDH}_{\mathrm{NC}}$.

processor from Laurell Technologies Corporation) on cleaned FTO glass substrates at $2000 \mathrm{rpm}$ for $2 \mathrm{~min}$. The films were vacuum-dried at $60{ }^{\circ} \mathrm{C}$ for $1 \mathrm{~h}$ and kept at room temperature for 1 day before analysis. Calcined films were obtained by thermal treatment under air at fixed temperatures for $4 \mathrm{~h}$. Porous thin films were prepared by mixing NiAl- $\mathrm{LDH}_{\mathrm{NC}}$ with Sikalatex dispersion $(12 \mathrm{wt} \%)$ containing stabilized latex nanoparticles with a diameter of $116 \mathrm{~nm}$ and zeta potential of $-48 \mathrm{mV}$. The $\mathrm{LDH} /$ latex weight ratio was fixed at 1:0.2, and $200 \mu \mathrm{L}$ of this mixture was deposited on the FTO substrate by spin coating, and subsequently, the sample was calcined at $400{ }^{\circ} \mathrm{C}$ for $4 \mathrm{~h}$ to remove the polymer beads, according to the temperature of decomposition of the beads determined by TGA.

2.3. Electrochromic Measurements. The electrochromic cell was assembled in a UV-vis quartz cell with a three-electrode system. The cell consists of LDH coated FTO as a working electrode, an Ag$\mathrm{AgCl}$ reference electrode, and $\mathrm{Pt}$ wire as a counter electrode. The electrochemical measurements (cyclic voltammetry (CV) and differential pulse amperometry (DPA)) were performed with a potentiostat BioLogic SP-150, and the in situ change in the optical transmittance was recorded with a UV-vis spectrophotometer (Shimadzu v-2400) at $400 \mathrm{~nm}$ wavelength. $0.1 \mathrm{M}$ aqueous solutions $(3 \mathrm{~mL}$ ) of sodium borate buffer ( $\mathrm{pH} 10), \mathrm{LiOH}, \mathrm{NaOH}, \mathrm{KOH}$, or $\mathrm{LiClO}_{4}$ were used as electrolytes. The effect of electroactive anions on the electrochromic properties was studied with $0.1 \mathrm{mM} \mathrm{K} \mathrm{K}_{4} \mathrm{Fe}(\mathrm{CN})_{6}, 0.1 \mathrm{mM} \mathrm{K} \mathrm{K}_{4} \mathrm{Ru}$ -

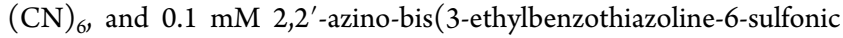
acid) (ABTS), purchased from Sigma-Aldrich.

2.4. Characterization Techniques. Powder X-ray diffraction (PXRD) measurements of $\mathrm{NiAl}-\mathrm{LDH}_{\mathrm{NC}}$ dried samples were performed using a Philips X'Pert Pro diffractometer using $\mathrm{Cu} \mathrm{K} \alpha$ radiation. Fourier transformed infrared (FTIR) spectra were recorded in transmission mode using the $\mathrm{KBr}$ pellet technique with a Nicolet 5700 spectrometer from Thermo Scientific. Thermogravimetric analyses (TGA) were made using a Setaram 92-16.16. Hydrodynamic diameters $(d, \mathrm{~nm})$ of $\mathrm{NiAl}-\mathrm{LDH}_{\mathrm{NC}}$ and latex beads were measured by dynamic light scattering (DLS) using a Zetasizer Nano ZS instrument (Malvern Instruments) in dilute conditions. Scanning electron microscopy (SEM) images of NiAl- $\mathrm{LDH}_{\mathrm{NC}}$ thin films were recorded using a JSM-7500F field emission scanning electron microscope. The film thicknesses were measured with an Alpha-step IQ surface profiler (KLA 134Tencor). The film optical indexes (refractive index and extinction coefficient) were determined from phase modulated spectroscopic ellipsometry measurements with a Jobin-Yvon UVISEL (0.75-4.75 eV and fixed $70^{\circ}$ incident angle) apparatus. The ellipsometric ratio $\rho=\tan \Psi \exp (j \Delta)$ was determined from the quantities Is $=\sin 2 \Psi \sin \Delta$ and Ic $=\sin 2 \Psi \cos \Delta$. The quantities Is and Ic were measured as a function of incident photon energy and compared to values deduced from a model describing the sample staking (substrate/film) and their optical properties. Different films were then simulated with a "New Amorphous" model.

\section{RESULTS AND DISCUSSION}

3.1. Analysis of NiAI-LDH Nanocluster Formation. The $\mathrm{NiAl}-\mathrm{LDH}$ nanoclusters $\left(\mathrm{NiAl}-\mathrm{LDH}_{\mathrm{NC}}\right)$ were successfully prepared by the epoxide route ${ }^{38,39}$ using propylene oxide (PO) and acetylacetone (acac) in high supersaturation conditions, as previously described by Tokudome et al. ${ }^{37}$ Dynamic light scattering analysis of the colloidal dispersion indicated the presence of nanoparticles with an average particle size of $9 \mathrm{~nm}$ (Figure 1A), in good agreement with the literature 

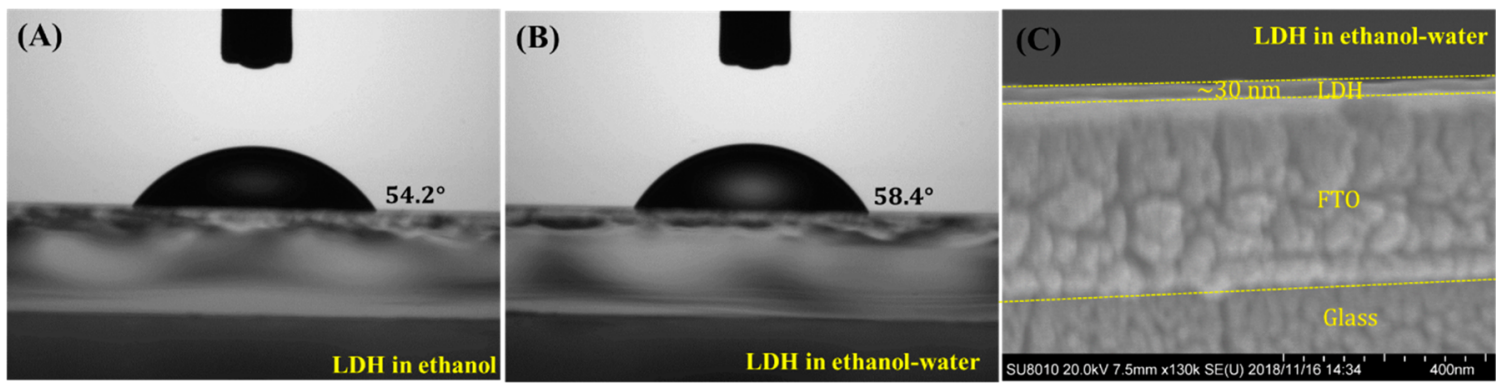

Figure 2. Photograph of the effect of LDH (25 g/L) dispersing solvent on the contact angle measurement (A, B) and SEM image (C) of NiAl$\mathrm{LDH}_{\mathrm{NC}}$ thin film.

and TEM image (Figure S1). ${ }^{37}$ As expected, the PXRD of $\mathrm{NiAl}-\mathrm{LDH}_{\mathrm{NC}}$ sol dried at $50{ }^{\circ} \mathrm{C}$ showed a typical pattern ascribed to the LDH phase in rhombohedral $(R \overline{3} \mathrm{~m})$ symmetry with $d_{003}$-spacing of $0.77 \mathrm{~nm}$ corresponding to $\mathrm{Cl}^{-}$interlayer anions (Figure 1B). The crystallite size, calculated from (003) basal reflection using the Scherrer method, is estimated at $\sim 6$ $\mathrm{nm}$. On the FTIR spectrum, the formation of LDH matrices is further confirmed by the presence of a broad band at 3443 $\mathrm{cm}^{-1}$, corresponding to the $-\mathrm{OH}$ stretching vibration, and the bands at 671 and $424 \mathrm{~cm}^{-1}$, attributed to $\nu_{\mathrm{MO}}$ and $\delta_{\mathrm{O}-\mathrm{M}-\mathrm{O}}$, respectively (Figure $1 \mathrm{C}$ ). Acac adsorption on the $\mathrm{NiAl}-\mathrm{LDH}_{\mathrm{NC}}$ surface was also shown by the bands at 2971 and $2931 \mathrm{~cm}^{-1}$, corresponding to the $-\mathrm{CH}$ stretching vibration, the intense band at $1594 \mathrm{~cm}^{-1}$, corresponding to $\mathrm{C}=\mathrm{O}$ stretching vibration, and the bands at $1529 \mathrm{~cm}^{-1}$, attributed to the CC stretching mode vibration of $\mathrm{Ni}$-acetyl acetonate. The bands at 1452 and $1392 \mathrm{~cm}^{-1}$ can be assigned to the $\delta \mathrm{C}=\mathrm{O}$ and $\nu$ $\mathrm{CH}_{3}$ of acac. ${ }^{30}$ The combustion of the acac ligands adsorbed on the NiAl- $\mathrm{LDH}_{\mathrm{NC}}$ induces two exothermic events on the TG curve occurring conjointly with the dehydroxylation of the metal hydroxide slabs and the removal of interlayer anions (Figure 1D). Due to the departure of adsorbed acac, a higher value of total weight loss (48.5\%) is obtained compared to the theoretical value of $37 \%$ expected for a $\mathrm{Ni}_{2} \mathrm{Al}(\mathrm{OH})_{6} \mathrm{Cl} \cdot 2 \mathrm{H}_{2} \mathrm{O}$ composition. Such an increase corresponds to roughly 0.72 mol of acac adsorbed per mole of LDH nanoclusters.

3.2. $\mathrm{NiAl}-\mathrm{LDH}_{\mathrm{NC}}$ Thin Films. The $\mathrm{LDH}$ thin films were prepared on FTO electrodes by spin coating using diluted $\mathrm{NiAl}-\mathrm{LDH}_{\mathrm{NC}}$ solutions. For a mass concentration of $25 \mathrm{~g} / \mathrm{L}$, the contact angle of thin films prepared using either ethanol $(\mathrm{EtOH})$ or a mixed ethanol/water $\left(\mathrm{EtOH} / \mathrm{H}_{2} \mathrm{O}\right.$ 0.38:0.62 v/v ratio) solution as solvent was almost the same. It suggests that the dispersion solvent does not modify the hydrophobic/ hydrophilic nature of the resulting $\mathrm{NiAl}-\mathrm{LDH}_{\mathrm{NC}}$ thin films (Figure 2A,B). However, the nature of the solvent has an effect on the spin-coating deposition process and strongly affects the thickness of the NiAl-LDH films, leading to values of 62 and $34 \mathrm{~nm}$ for ethanol and the mixed $\mathrm{EtOH} / \mathrm{H}_{2} \mathrm{O}$ dispersion at 25 $\mathrm{g} / \mathrm{L}$, respectively (Table 1 ). The deposition of a lesser amount of $\mathrm{LDH}$ from the mixed $\mathrm{EtOH} / \mathrm{H}_{2} \mathrm{O}$ solution could be related to the difference in wettability of the FTO substrate, displaying a contact angle value of $83^{\circ}$ for a droplet of water compared to $21^{\circ}$ for a droplet of ethanol. Thin films were prepared using $\mathrm{LDH}$ concentrations of $1-50 \mathrm{~g} / \mathrm{L}$ in mixed $\mathrm{EtOH} / \mathrm{H}_{2} \mathrm{O}$ solvent, and their thickness was determined. Obviously, the film thickness increases with the increase in the $\mathrm{LDH}$ concentration used up to $50 \mathrm{~g} / \mathrm{L}$ with a quasi-linear behavior from 10 to $50 \mathrm{~g} / \mathrm{L}$ (Table 1, Figure S2).
Table 1. Effect of the NiAl- $\mathrm{LDH}_{\mathrm{NC}}$ Amount in EtOH/ $\mathrm{H}_{2} \mathrm{O}$ (0.38:0.62 v/v ratio) on the Film Thickness and Change in Transmittance $(\Delta T, \%)$ during Electrochromic Measurements

\begin{tabular}{|c|c|c|}
\hline amount of LDH $(\mathrm{g} / \mathrm{L})$ & average film thickness ${ }^{a}(\mathrm{~nm})$ & $\Delta T^{b}(\%)$ \\
\hline 1 & 3 & 4 \\
\hline 5 & 3 & 13 \\
\hline 10 & 4 & 20 \\
\hline 25 & 34 & 30 \\
\hline 50 & 112 & 14 \\
\hline $25^{c}$ & 62 & 28 \\
\hline
\end{tabular}

${ }^{a}$ Films prepared by spin coating: $200 \mu \mathrm{L}$ of sample, $2000 \mathrm{rpm}$ for 2 min; drying: $60{ }^{\circ} \mathrm{C}$ vacuum for $1 \mathrm{~h}$ followed by $24 \mathrm{~h}$ at RT. ${ }^{b}$ Calculated from DPA measurements, $1.2 \mathrm{~V}$ pulse height, $480 \mathrm{~s}$ pulse width. ${ }^{c}$ Film prepared in EtOH.

In good agreement with the value obtained with the profilometer $(34 \mathrm{~nm})$ (Table 1), the cross-sectional SEM image of the NiAl- $\mathrm{LDH}_{\mathrm{NC}}$ thin film deposited from the mixed $\mathrm{EtOH} / \mathrm{H}_{2} \mathrm{O}$ solvent $(25 \mathrm{~g} / \mathrm{L})$ clearly shows a thickness of $\sim 30$ $\mathrm{nm}$ (Figure 2C).

3.3. Electrochromic Behavior of NiAl-LDH Nanocluster Thin Films. The electrochemical response of NiAl$\mathrm{LDH}_{\mathrm{NC}}$ thin films coated on FTO in borate buffer $(\mathrm{pH} 10)$ is characterized in cyclic voltammetry by a progressive activation process (Figure S3). The typical electrochemical signals observed in the potential window between 0.0 and $1.2 \mathrm{~V} /$ $\mathrm{Ag}-\mathrm{AgCl}$ correspond to the quasi-reversible oxidation of $\mathrm{Ni}(\mathrm{II})$ sites in the LDH lattice governed by an ion diffusional process associated with an electron hopping mechanism in the bulk of the material. ${ }^{40,41}$ The oxidation of NiAl- $\mathrm{LDH}_{\mathrm{NC}}$ is accompanied by a color change from clear to dark brown. ${ }^{32}$ However, Villemure and co-workers ${ }^{32}$ (and the cited references therein) have shown that the conductivity of fully reduced NiAl-LDH film is much lower than that of the partially oxidized film. Consequently, the formation of this reduced insulating phase at the interface between the $\mathrm{LDH}$ and FTO electrode slows down the reduction progress of nickel sites in the bulk of the film, leading to a shift of reduction potential $\left(E p_{c}\right)$ toward more cathodic values (Figure S3). Hence, the bleaching back to the transparent state occurring upon reduction may become a limiting step in the electrochromic application. Initial investigations were performed to study the influence of the thin film preparation, of the nature of the electrolyte, and of the presence of electroactive ions on the electrochromic ability.

3.3.1. Electrochromic Properties of Thin Films in Borate Buffer. Upon potential scanning in $\mathrm{CV}$, the thin films prepared from NiAl- $\mathrm{LDH}_{\mathrm{NC}}$ diluted in the two different solvents at 25 $\mathrm{g} / \mathrm{L}$, namely, EtOH and $\mathrm{EtOH} / \mathrm{H}_{2} \mathrm{O}$ (0.38:0.62 v/v ratio), 

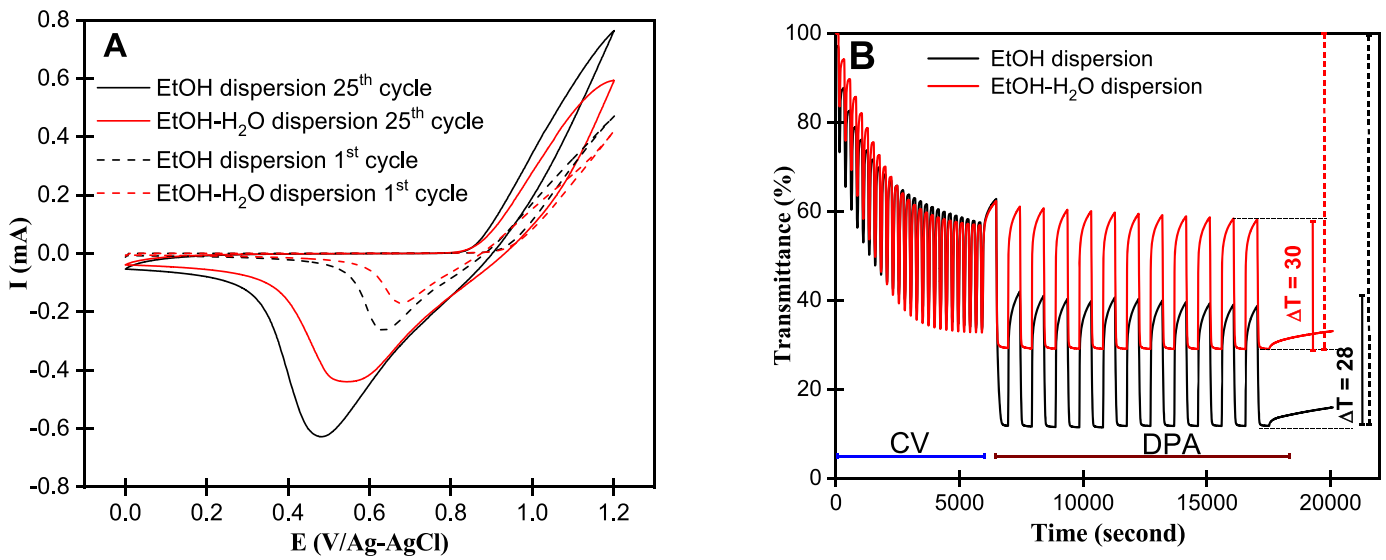

Figure 3. Effect of the dispersing solvent $\left(\mathrm{NiAl}-\mathrm{LDH}_{\mathrm{NC}} 25 \mathrm{~g} / \mathrm{L}\right)$ on $(\mathrm{A}) \mathrm{CV}\left(1^{\text {st }}\right.$ and $25^{\text {th }}$ cycle) and (B) UV-vis transmittance changes at $400 \mathrm{~nm}$ (electrolyte, $0.1 \mathrm{M}$ borate buffer, $\mathrm{pH} 10 ; \mathrm{CV}$ at $v=10 \mathrm{mV} / \mathrm{s}$; DPA: $1.2 \mathrm{~V}$ pulse height; $480 \mathrm{~s}$ pulse width).
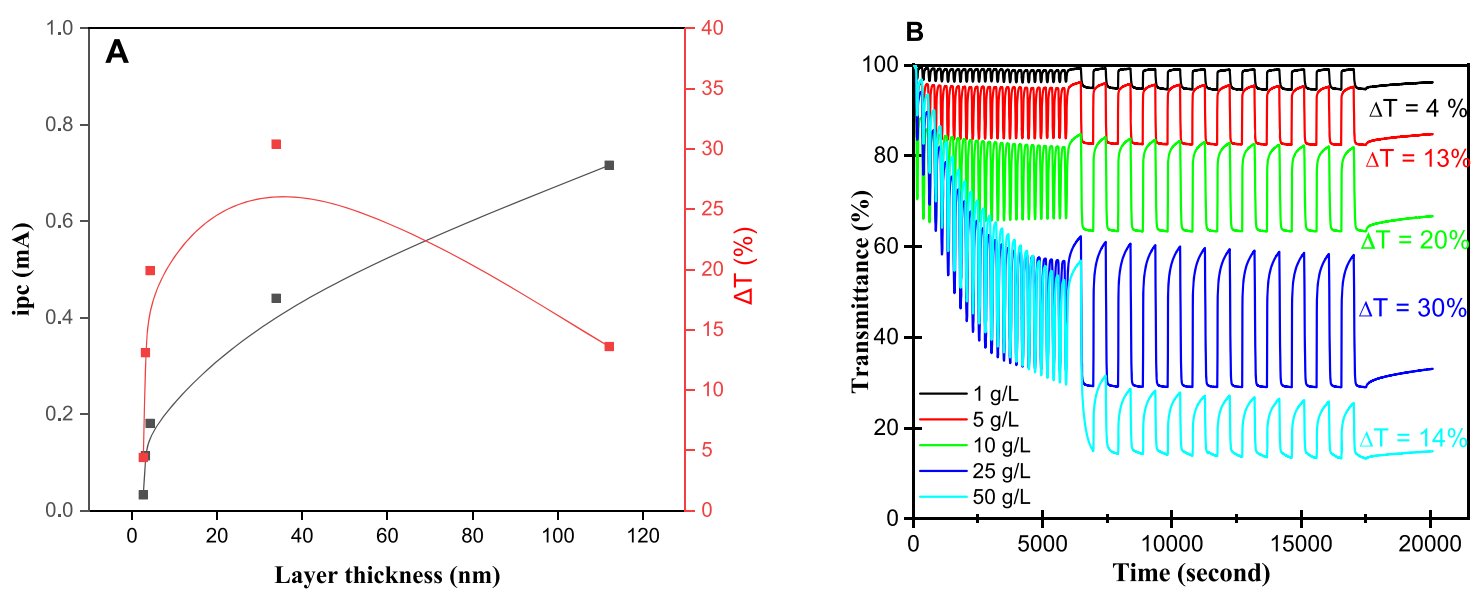

Figure 4. Effect of the thickness of the NiAl- $\mathrm{LDH}_{\mathrm{NC}}$ thin films on the electrochromic ability. (A) Changes in the cathodic peak current $\left(i_{\mathrm{pc}}\right)$ and electrochromic contrast $(\Delta T)$. (B) UV-vis transmittance change at $400 \mathrm{~nm}$ (electrolyte, $0.1 \mathrm{M}$ borate buffer, $\mathrm{pH} 10 ; \mathrm{CV}$ at $v=10 \mathrm{mV} / \mathrm{s} ; \mathrm{DPA}: 1.2$ $\mathrm{V}$ pulse height, $480 \mathrm{~s}$ pulse width).

showed a broad and nondefinite oxidation peak and a more definite reduction peak (Figure 3A). The cyclic voltammograms of the thin film prepared using ethanol as dispersant evidenced a cathodic peak current $\left(i_{\mathrm{pc}}\right)$ of $-0.26 \mathrm{~mA}$ at $0.64 \mathrm{~V}$ in the first cycle, which was increased at the 25th cycle to $-0.63 \mathrm{~mA}$ at $0.48 \mathrm{~V}$. Comparatively, a slightly lower peak current of $-0.17 \mathrm{~mA}$ at $0.68 \mathrm{~V}$ in the first cycle and $-0.44 \mathrm{~mA}$ at $0.54 \mathrm{~V}$ in the 25 th cycle was observed for the film prepared from the ethanol-water dispersion. Figure $3 \mathrm{~B}$ shows the transmittance of the NiAl- $\mathrm{LDH}_{\mathrm{NC}}$ thin films as a function of time recorded in situ at $400 \mathrm{~nm}$ during the potential scans in $\mathrm{CV}$ for 25 cycles at a scan rate $(v)$ of $10 \mathrm{mV} / \mathrm{s}$ and then during successive differential chronoamperometry pulses (DPA) between $E_{\text {app }}=0.0 \mathrm{~V}$ (reduced film) and $1.2 \mathrm{~V}$ (oxidized film) for a $480 \mathrm{~s}$ pulse width. The total measurement was carried out for around $5 \mathrm{~h}$ to study the stability of the electrochromic systems. The progressive increase of the current intensity upon potential cycling in CV ( 25 cycles) is accompanied by a progressive decrease of the transmittance of the films.

This coloration of the films upon oxidation is not fully reversible upon the cathodic polarization, causing a decrease of the transmittance from $100 \%$ to $\sim 60 \%$ for the reduced films. Such behavior was explained by the formation of an insulating layer at the $\mathrm{LDH}$ film/FTO electrode interface, hampering an efficient full reduction of the nickel sites. ${ }^{32}$ Moreover, the contrast between the oxidized and the reduced form of both types of films after the $25^{\text {th }}$ cycle is almost similar to the change in transmittance $(\Delta T)$ of $\cong 30 \%$, irrespective of the film thickness ranging from 34 to $62 \mathrm{~nm}$. However, different electrochromic characteristics were observed in DPA analysis for both cases. The coloring and bleaching efficiency in the transmittance is between $12 \%$ and $40 \%(\Delta T=28 \%)$ for the film prepared from ethanol dispersion (Figure 3B). Conversely, the film prepared from an ethanol-water $\mathrm{NiAl}-\mathrm{LDH}_{\mathrm{NC}}$ dispersion showed a transmittance change from $32 \%$ to $62 \%$ $(\Delta T=30 \%)$, which is almost equal to coloring-bleaching changes observed during CV scans. This difference in electrochromic behavior can be due to the film thickness (Table 1); a longer oxidation time was necessary to oxidize a thicker film due to diffusional limitations.

To get further insight into the impact of the film thickness, the electrochromic properties of $\mathrm{NiAl}-\mathrm{LDH}_{\mathrm{NC}}$ thin films, prepared with different concentrations $(1-50 \mathrm{~g} / \mathrm{L})$ in the ethanol-water mixture, were then investigated. Undeniably, the electrochemical response, recorded in $\mathrm{CV}$, depends on the amount of NiAl- $\mathrm{LDH}_{\mathrm{NC}}$ deposited on the FTO surface (Figure S4) and hence on the film thickness. Indeed, as shown in Figure $4 \mathrm{~A}$, the cathodic current $\left(i_{\mathrm{pc}}\right)$ increases with the layer thickness. However, the electrochemical response becomes 


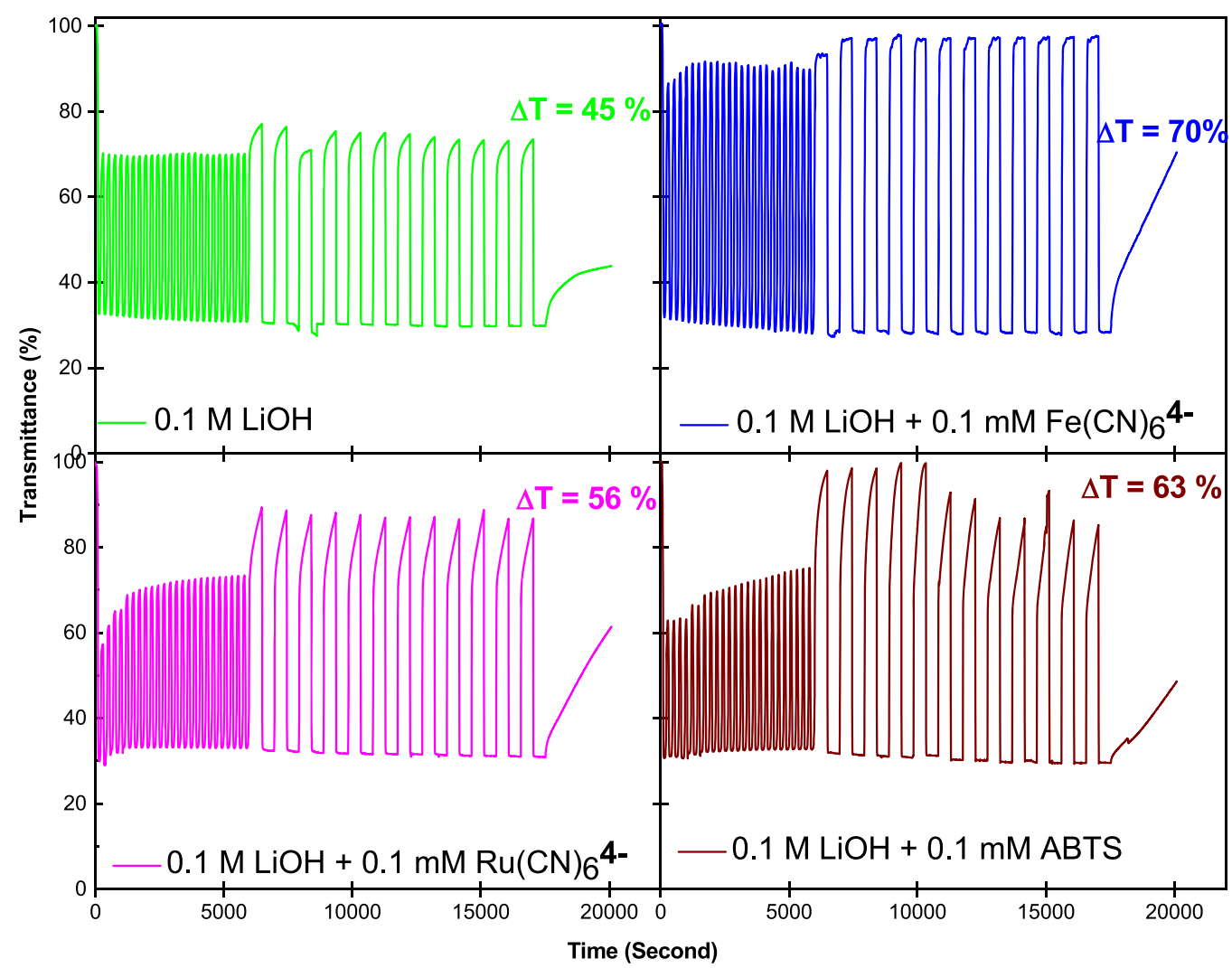

Figure 5. Role of electroactive anions on the electrochromic ability of $\mathrm{NiAl}-\mathrm{LDH}_{\mathrm{NC}}$ thin films: $\mathrm{UV}-$ vis transmittance change upon $\mathrm{CV}$ at $v=10$ $\mathrm{mV} / \mathrm{s}$ and DPA with $1.2 \mathrm{~V}$ pulse height and $480 \mathrm{~s}$ pulse width.

limited for the thicker films in which the reduction progress becomes more difficult, as shown by the shift of the $\mathrm{Ep}_{\mathrm{c}}$ (Figure S4). The in situ transmittance transients indicate that the electrochromic contrast $(\Delta T)$ increases until an optimal film thickness of $34 \mathrm{~nm}$ at $30 \%$ (Figure $4 \mathrm{~B}$ ). Thicker film (112 $\mathrm{nm}$ ) obtained from $50 \mathrm{~g} / \mathrm{L}$ dispersion leads to a lower $\Delta T$ value (14\%) with low bleaching reversibility. It is worth mentioning here that even if the thinner films display moderate $\Delta T$ values, the reversibility of the bleaching corresponding to $\mathrm{Ni}^{3+}$ to $\mathrm{Ni}^{2+}$ reduction is almost constant in $\mathrm{CV}$ and DPA, probably due to the low film thickness and an efficient diffusion within the whole film. At $25 \mathrm{~g} / \mathrm{L}$, the reversibility is limited but shows higher contrast, which provides room for further exploration. Hence, the film prepared from a $25 \mathrm{~g} / \mathrm{L}$ $\mathrm{LDH}$ concentration in the ethanol-water mixture was chosen in the following to further explore the electrochromic behavior.

3.3.2. Effect of Electrolyte Solution on the Electrochromic Properties of the Thin Films. In a previous study, we have shown that the electrochemical response of NiAl-LDH films depends on the $\mathrm{pH}$ and the composition of electrolytes. ${ }^{40}$ To improve the coloration-bleaching efficiency, different electrolytes, such as $0.1 \mathrm{M}$ sodium borate buffer $(\mathrm{pH}=10), \mathrm{LiOH}$, $\mathrm{NaOH}, \mathrm{KOH}(\mathrm{pH} \cong 13)$, and $\mathrm{LiClO}_{4}(\mathrm{pH} \cong 7)$, were tested. Figure S5A confirms that the peak position and current intensity recorded in $\mathrm{CV}$ depend on the $\mathrm{pH}$ and to a certain extent on the nature of alkali cations in the electrolyte. With the electrochemical transfer being more efficient in alkaline medium, the peaks are shifted toward less anodic potentials and the current intensity increases. Concerning the electrochromic properties in $\mathrm{LiClO}_{4}$, the films displayed lower contrast than in the other electrolytes $(\Delta T \cong 10 \%)$ due to a smaller amount of $\mathrm{Ni}$ sites involved in the electrochemical transfer (Figure S5B). In comparison with borate buffer solution, the electrolytes based on alkali metal hydroxide, i.e., $\mathrm{LiOH}, \mathrm{NaOH}$, and $\mathrm{KOH}$, immediately showed a stable electrochromic response upon potential cycling in $\mathrm{CV}$ with a minimum transmittance of $\sim 30 \%$ and a contrast $\Delta T \cong 39 \%$ (Figure $\mathrm{S} 5 \mathrm{~B}$ ). $\mathrm{LiOH}$ was chosen as a supporting electrolyte in the following.

3.3.3. Effect of Electroactive Ions on the Electrochromic Properties of the Thin Films. Under these experimental conditions, the bleaching of the colored film was not completely reversible, with only $\sim 70 \%$ of transmittance for the reduced form of the films. Villemure and co-workers have shown that the presence electroactive ions in the electrolyte, i.e., $\mathrm{Ru}(\mathrm{bpy})_{3}{ }^{2+}, \mathrm{Co}(\mathrm{bpy})_{3}{ }^{2+}, \mathrm{Fe}(\mathrm{CN})_{6}{ }^{4-}$, and $\mathrm{Ru}(\mathrm{CN})_{6}{ }^{4-}$, may improve the contrast between the bleaching and the colored states of the NiAl-LDH transparent electrodes, ${ }^{32-34}$ the electroactive anions playing the role of electron mediators in the electrochemical process.

Figure $\mathrm{S} 6$ shows the transmittance of $\mathrm{NiAl}-\mathrm{LDH}_{\mathrm{NC}}$ as a function of applied potential recorded in situ during the $25^{\text {th }}$ potential scan in $0.1 \mathrm{M} \mathrm{LiOH}$ containing different electroactive ions $\left(0.1 \mathrm{mM} \mathrm{Fe}(\mathrm{CN})_{6}^{4-}, \mathrm{Ru}(\mathrm{CN})_{6}^{4-}\right.$, and $\left.\mathrm{ABTS}\right)$. With $\mathrm{Ru}(\mathrm{CN})_{6}{ }^{4-}$, there is no significant modification of the transmittance transient from that obtained in the blank electrolyte. The transmittance of the film drops rapidly when the potential reaches the foot of the oxidation peak at $\sim 0.6 \mathrm{~V}$ and remains stable until the potential returns to $\sim 0.4 \mathrm{~V}$ where the electrochemical reduction process begins. In all cases, the same minimal transmittance value was reached $(\sim 30 \%)$; this value depends on the optimum film thickness. In the presence of ABTS, the peaks in the CV are slightly shifted toward less anodic potentials, but there is no significant change in 
electrochromic contrast, similar to $\mathrm{Ru}(\mathrm{CN})_{6}{ }^{4-}$. However, with $\mathrm{Fe}(\mathrm{CN})_{6}{ }^{4-}$, the transmittance of the reduced film returns to nearly $90 \%$, leading to an enhancement of the electrochromic contrast. As already observed by Villemure and co-workers, ${ }^{32}$ the bleaching of the film occurs in two steps, the first one corresponding to the direct reduction of $\mathrm{Ni}$ sites in the $\mathrm{LDH}$ and the second to the mediated reduction by $\mathrm{Fe}(\mathrm{CN})_{6}$, which remains an efficient mediator for the reduction in basic medium. The same tendency was clearly observed in DPA experiments (Figure 5), highlighting the intrinsic advantage of using $\mathrm{Fe}(\mathrm{CN})_{6}^{4-}$ as a redox mediator.

These data can be advantageously compared with the values reported in the literature for other NiAl-LDH EC devices (Table S1), in particular with those analyzed in situ during CV $(\approx 15-20$ scans) in borate buffer in the presence of $\mathrm{Fe}(\mathrm{CN})_{6}^{4-}$. In all cases with the help of this redox mediator, the color changes were reversible with a transmittance returning to nearly $90-100 \%$ at the end of each scan. However, the oxidized colored states were less dark. For instance, a NiAl-LDH thin film, prepared from a classical coprecipitated LDH phase, displayed contrast values $(\Delta T)$ of $35 \%$ and $10 \%$ in borate buffer solution at $\mathrm{pH} 8$ and 10 , respectively. ${ }^{32}$ Similar values are reported for a porous and nonporous $\mathrm{NiAl}-\mathrm{LDH}$ thin film prepared by electrogeneration, with a maximum $\Delta T$ value of $\approx 30 \% .^{31}$ Moreover, with NiAl$\mathrm{LDH}_{\mathrm{NC}}$, the electrochromic response in the presence of $\mathrm{Fe}(\mathrm{CN})_{6}{ }^{4-}$ is stable and reproducible over a long time $(>3 \mathrm{~h})$ when recorded in DPA (Figure 5), with $98 \%$ of the transmittance for the reduced film and a $\Delta T \cong 70 \%$, which is much higher than in the blank $\mathrm{LiOH}$ solution or with the other electroactive molecules (Table S1).

The electrochromic performance of the thin films is generally relevant to a short switching time of coloration and bleaching. ${ }^{42,43}$ The color switching time of the NiAl- $\mathrm{LDH}_{\mathrm{NC}}$ thin film was therefore studied using DPA with an alternative bias from 0 to $1.2 \mathrm{~V}$ and a short pulse width of $60 \mathrm{~s}$. (Figure 6).

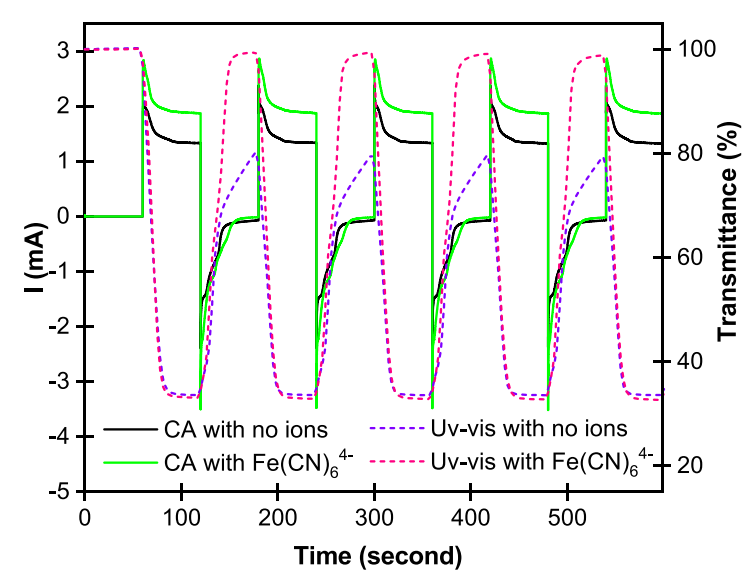

Figure 6. Chronoamperogram and transmittance changes of NiAl$\mathrm{LDH}_{\mathrm{NC}}$ thin films in $0.1 \mathrm{M} \mathrm{LiOH}$ solution with and without $0.1 \mathrm{mM}$ $\mathrm{Fe}(\mathrm{CN})_{6}{ }^{4-}$ (DPA with $1.2 \mathrm{~V}$ pulse height and $60 \mathrm{~s}$ pulse width).

These transmission transients clearly show that the bleaching process in $\mathrm{LiOH}$ is slow and the transmittance reached after $60 \mathrm{~s}$ was around $80 \%$. In the presence of $\mathrm{Fe}(\mathrm{CN})_{6}{ }^{4-}$, the bleaching process becomes faster, and a stable transmittance of $\sim 98 \%$ is reached after less than $30 \mathrm{~s}$. The kinetics of coloration seems to be similar in both media with an average response time of around $25 \mathrm{~s}$.
3.4. Electrochromic Ability of the Thin Films of NiAl$\mathrm{LDH}_{\mathrm{NC}}$ Derived Mixed Oxides. Since the NiO films have been deeply studied as materials for electrochromism in the literature, showing that the $\mathrm{NiO}$ electrochromic properties were strongly dependent on the annealing temperature, ${ }^{31,44}$ the effect of a moderate thermal treatment of the NiAl-LDH $\mathrm{LC}_{\mathrm{NC}}$ thin film on the electrochromic response was also investigated. As previously evidenced by TGA (Figure 1D), NiAl-LDH $\mathrm{LC}_{\mathrm{NC}}$ films are decomposed through dehydration and dehydroxylation of the metal hydroxide slabs. These two steps occur conjointly with the exothermic acac combustion. PXRD patterns of $\mathrm{NiAl}-\mathrm{LDH}_{\mathrm{NC}}$ were recorded after calcination at different temperatures (Figure S7) showing a typical LDH decomposition behavior. ${ }^{45,46}$ The $\mathrm{LDH}$ layered structure is maintained during the dehydration steps up to $200{ }^{\circ} \mathrm{C}$ despite partial amorphization traduced by a net decrease of the reflection intensity. Above this temperature, the lamellar structure collapses, and the diffraction lines of $\mathrm{NiO}$ and $\mathrm{NiAl}_{2} \mathrm{O}_{4}$ spinel phases begin to appear, becoming more intense at higher temperatures because of the crystallization of the oxide phases.

3.4.1. Calcination Temperature of NiAl- $L D H_{N C}$ Thin Films. The NiAl- $\mathrm{LDH}_{\mathrm{NC}}$ films were heated at 200, 300, 400, and 500 ${ }^{\circ} \mathrm{C}$. Ellipsometric measurements were performed to determine the refractive index $n$ and the geometrical thickness of the films after these thermal treatments. The obtained results (Table 2) indicate a decrease of the film thickness from 28 to $19 \mathrm{~nm}$. Such sintering is accompanied by an increase of the refractive index from 1.7 before to 1.8-1.9 after thermal treatment. Both phenomena could be interpreted as film densification after LDH decomposition.

The evolution of the in situ transmittance transients as a function of the calcination temperature of $\mathrm{NiAl}-\mathrm{LDH}_{\mathrm{NC}}$ films (Figure S8) indicated that the annealing treatments increased the bleaching reversibility from $200{ }^{\circ} \mathrm{C}$ and reached a maximal value for thermal treatment at $400{ }^{\circ} \mathrm{C}$. However, it is noteworthy that, above $200{ }^{\circ} \mathrm{C}$, the coloration efficiency decreased and the darkening of the oxidized films became less stable upon continuous potential cycling with a progressive decrease in the transmittance. After 25 cycles, mixed $\mathrm{NiO} /$ $\mathrm{NiAl}_{2} \mathrm{O}_{4}$ film formed at $400{ }^{\circ} \mathrm{C}$ has a minimum transmittance of only $65 \%$ and an electrochromic contrast $\Delta T \cong 35 \%$ (Table $2)$. The film annealed at $500{ }^{\circ} \mathrm{C}$, the highest temperature tested, displayed lower coloration (74\%) and a smaller color change $(\Delta T \cong 20 \%)$. Similarly, Chen et al. reported that the calcination of nickel oxide films at high temperatures $(T>300$ ${ }^{\circ} \mathrm{C}$ ) was deleterious to their EC properties. ${ }^{44}$

3.4.2. Porosity in the Calcinated NiAl- $L_{D C} H_{N C}$ Thin Films. One possibility to limit such a decrease of the performance could be to introduce porosity. Indeed, according to Villemure and co-workers, the creation of macroporosity in the film can enhance the permeability of electrolyte/electroactive ions through the film and hence improve the electrochromic properties. ${ }^{31}$ Generally, polystyrene beads are used as a sacrificial template for the generation of macroporosity in inorganic materials. ${ }^{47,48}$ In our case, since the positively charged $\mathrm{LDH}_{\mathrm{NC}}$ heterocoagulate with classical negatively charged polystyrenesulfonate beads, producing opaque inhomogeneous thin films by spin coating, commercially available stabilized latex beads were used for the preparation of porous mixed oxides derived from the NiAl- $\mathrm{LDH}_{\mathrm{NC}}$ thin film. Typically, the film was prepared by spin coating of a mixed dispersion of $\mathrm{NiAl}-\mathrm{LDH}_{\mathrm{NC}}$ and latex beads (weight ratio 
Table 2. Effect of the Temperature of Calcination of $\mathrm{NiAl}-\mathrm{LDH}_{\mathrm{NC}}$ Thin Films on the Film Properties and Their Electrochromic Behavior

\begin{tabular}{|c|c|c|c|c|c|}
\hline temperature of calcination $\left({ }^{\circ} \mathrm{C}\right)$ & refractive index, $n$ & thickness (nm) & $\Delta T(\%)^{a}$ & transmittance $\max (\%)$ & transmittance $\min (\%)$ \\
\hline 60 & 1.67 & 28 & 40 & 70 & 30 \\
\hline 20 & 1.94 & 19 & 50 & 83 & 33 \\
\hline 300 & 1.92 & 19 & 50 & 96 & 46 \\
\hline 400 & 1.78 & 24 & 35 & 100 & 65 \\
\hline 500 & 1.81 & 18 & 20 & 94 & 74 \\
\hline porous 400 & 1.30 & 32 & 49 & 91 & 42 \\
\hline
\end{tabular}
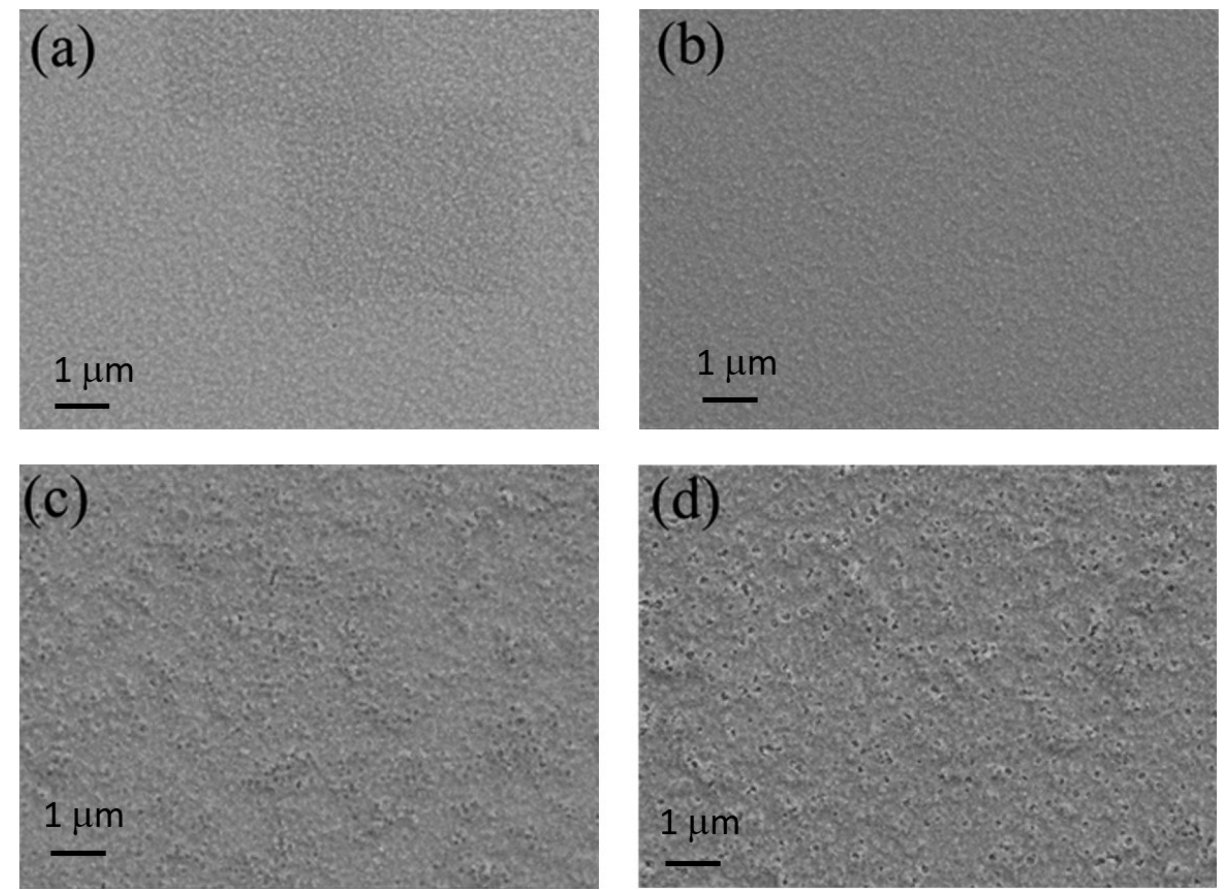

Figure 7. SEM images of $(\mathrm{a}, \mathrm{b}) \mathrm{NiAl}-\mathrm{LDH}_{\mathrm{NC}}$ and $(\mathrm{c}, \mathrm{d}) \mathrm{NiAl}-\mathrm{LDH}_{\mathrm{NC}}$-latex $(1: 02)$ composite thin films before and after calcination at $400{ }^{\circ} \mathrm{C}$ under air.
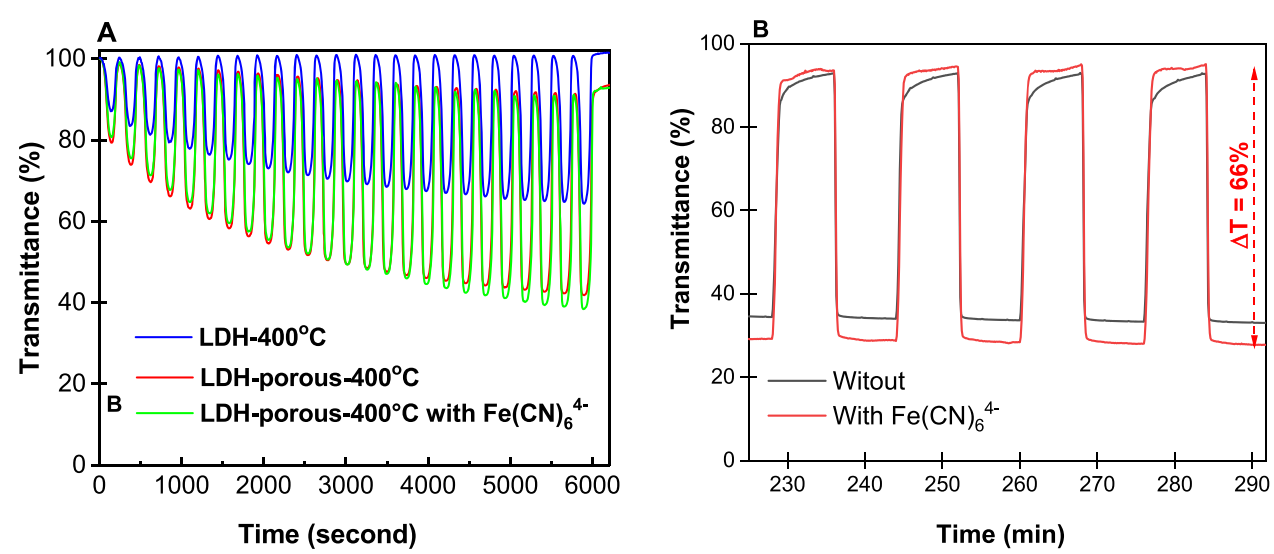

Figure 8. Effect of film porosity on the electrochromic ability of calcined NiAl-LDH $\mathrm{NC}_{\mathrm{N}}$ thin films. UV-vis transmittance changes upon (A) CV (in $0.1 \mathrm{M} \mathrm{LiOH}, v=10 \mathrm{mV} / \mathrm{s}$ ) and (B) DPA (pulse height of $1.2 \mathrm{~V}$, pulse width of $480 \mathrm{~s}$ ) of porous films.

$1 / 0.2)$; the porosity was subsequently generated by calcination of the polymeric sacrificial template. Compared to the NiAl$\mathrm{LDH}_{\mathrm{NC}}$ films, which show little change in their appearance except for a smoother surface after calcination at $400{ }^{\circ} \mathrm{C}$ (Figure 7), large macropores are clearly observed in the NiAl$\mathrm{LDH}_{\mathrm{NC}}$-latex composite thin film after calcination (Figure 7). From ellipsometric measurements, the porous film seems to be slightly absorbent in the visible light range, which could reveal that some polymer residues remain in the film. The sample is then modeled as a gradient layer from a bottom composed of a $\mathrm{NiAl}-\mathrm{LDH}_{\mathrm{NC}} /$ latex mixture and a top containing only NiAl$\mathrm{LDH}_{\mathrm{NC}}$. An exponential gradient is used, consistent with a diffusion of latex calcination byproducts. Hence, a total film thickness of $32 \mathrm{~nm}$ is found with a refractive index of the top 
layer of 1.30 , significantly lower than for $\mathrm{NiAl}-\mathrm{LDH}_{\mathrm{NC}}$ film annealed at $400{ }^{\circ} \mathrm{C}$ (Table 2).

The permeability properties of the films were then studied in $\mathrm{CV}$ using potassium ferrocyanide as a reversible redox probe. To limit the interference with the electrochemical signal of $\mathrm{Ni}$ sites in the $\mathrm{LDH}$, the $\mathrm{CV}$ was recorded at $0.1 \mathrm{mM} \mathrm{FeCN}_{6}{ }^{4-}$ in neutral medium $(0.1 \mathrm{M} \mathrm{KCl})$ (Figure S9A). The full coverage of FTO electrodes by NiAl-LDH $\mathrm{NC}_{\mathrm{NC}}$ or the NiAl-LDH $\mathrm{NC}$-latex mixture caused a decrease in the electrochemical signal, owing to the impossibility of the electroactive probe to reach the electrode surface. After template removal, well-defined peaks are observed, indicating fast diffusion through the porous films. On the basis of the variation of the anodic current $\left(i_{\mathrm{pa}} / \mathrm{A}\right)$ as a function of the square root of the scan rate $\left(v^{1 / 2}\right)$ (Figure S9B), apparent diffusion coefficients $\left(D_{\text {app }}\right)$ were calculated from the Randles-Sevcik equation (eq 1 ) for each type of modified electrode:

$$
i_{\mathrm{p}}=2.69 \times 10^{5} n^{3 / 2} A C v^{1 / 2} D^{1 / 2}
$$

where $n=1 \mathrm{e}^{-}$transfer, $C=1 \times 10^{-7} \mathrm{~mol} \mathrm{~cm} \mathrm{~cm}^{3}$, and $A=$ electrode surface $\left(\sim 3 \mathrm{~cm}^{2}\right)$. With the calcined NiAl-LDH $\mathrm{NC}^{-}$ latex, the $D_{\text {app }}$ value is close to the value obtained at a bare FTO electrode. These results confirm that the porosity of the film is drastically increased using the latex template. Indeed, calcination of the $\mathrm{NiAl}-\mathrm{LDH}_{\mathrm{NC}}$ thin film at $400{ }^{\circ} \mathrm{C}$ increases the diffusion of the electrochemical probe but to a lesser magnitude.

Concerning the EC properties, after 25 cycles, the coloration of the porous calcined NiAl- $\mathrm{LDH}_{\mathrm{NC}}$ film is more intense $(T \cong$ $42 \%)$ than for the nonporous calcined film $(T \cong 65 \%)$ (Figure $8 \mathrm{~A})$. The same behavior was described by Villemure and coworkers for electrogenerated NiAl-LDH films. ${ }^{31}$ Apparently, the presence of the electroactive anion $\mathrm{FeCN}_{6}{ }^{4-}$ has no significant effect on the EC response of the porous calcined $\mathrm{NiAl}-\mathrm{LDH}_{\mathrm{NC}}$ film (Figure $8 \mathrm{~A}$ ), but the bleaching-coloration process seems to be slightly improved with a shorter response time observed in DPA (Figure $8 \mathrm{~B}$ ) and a contrast $\Delta T$ of $66 \%$. The porosity of the films improves the electrochromic properties of $\mathrm{NiAl}-\mathrm{LDH}_{\mathrm{NC}}$ derived mixed oxides, but the activation by potential cycling becomes necessary before reaching a steady state; the contrast $(\Delta T)$ remains lower than the EC response obtained under the same experimental conditions with the pristine $\mathrm{NiAl}-\mathrm{LDH}_{\mathrm{NC}}$ film (Figure 5). These results confirm that $\mathrm{NiAl}-\mathrm{LDH}_{\mathrm{NC}}$ films are good candidates for EC applications with fast, reversible, and stable transmittance changes of $70 \%$.

\section{CONCLUSION}

The NiAl-LDH nanocluster suspension was easily prepared using the epoxide method, allowing the preparation of homogeneous, tunable, and transparent thin films on the FTO substrate by spin-coating. The thickness of the films can be easily tuned from a few nanometers to $112 \mathrm{~nm}$ by using suspensions of nanoclusters with concentrations ranging from 1 to $50 \mathrm{~g} / \mathrm{L}$. NiAl- $\mathrm{LDH}_{\mathrm{NC}}$ films display interesting electrochromic properties switching reversibly from white to brown color upon cycling. The optical properties of the NiAl- $\mathrm{LDH}_{\mathrm{NC}}$ films measured during potential scans in CV or DPA strongly depend on parameters such as the film thickness, the nature of the electrolyte, and the presence of electroactive anions.

We showed that an optimized variation of transmission $(\Delta T)$ of $70 \%$ can be obtained for a $34 \mathrm{~nm}$ thick film in $\mathrm{LiOH}$ and the presence of $0.1 \mathrm{mM} \mathrm{Fe}(\mathrm{CN})_{6}{ }^{4-}$. The presence of electroactive ions in the electrolyte accelerates the bleaching process, leading to a stable transmittance of $\sim 98 \%$ after less than $30 \mathrm{~s}$. To our knowledge, compared to the previous studies reported in the literature on electrochromic properties of $\mathrm{LDH}$ materials, ${ }^{32}$ our films prepared from the NiAl-LDH nanoclusters display much better performance. The creation of porosity in the calcined film using a sacrificial polymeric template appears as an advantageous alternative for the mixed oxide films formed at $400{ }^{\circ} \mathrm{C}$. The electrochromic contrast increases from $35 \%$ to $49 \%$ for the nonporous and porous films annealed at $400{ }^{\circ} \mathrm{C}$, respectively. Finally, our results confirm that NiAl-based $\mathrm{LDH}$ films are promising materials for electrochromic applications in the field of smart windows or low-power displays. The use of $\mathrm{LDH}$ nanoclusters to prepare the film allowed the electrochromic performances to be improved, and further improvements can be expected with the preparation of porous and nanostructured $\mathrm{LDH}$ thin films without the calcination step and the use of nonaqueous electrolytes.

\section{ASSOCIATED CONTENT}

\section{Supporting Information}

The Supporting Information is available free of charge at https://pubs.acs.org/doi/10.1021/acsanm.0c01026.

TEM image; correlation between film thickness and $\mathrm{NiAl}-\mathrm{LDH}_{\mathrm{NC}}$ concentration used; cyclic voltammograms; effect of the LDH concentration on the voltammograms; effect of electrolyte on the electrochromic ability of NiAl- $\mathrm{LDH}_{\mathrm{NC}}$ thin films; effect of electroactive anions on the coloring and bleaching of NiAl-LDH $\mathrm{NC}_{\mathrm{NC}}$ thin films; PXRD patterns; effect of calcination temperature of $\mathrm{NiAl}-\mathrm{LDH}_{\mathrm{NC}}$ films on the UV-vis transmittance change; electrochromic performance (PDF)

\section{AUTHOR INFORMATION}

\section{Corresponding Authors}

Vanessa Prevot - Universite Clermont Auvergne, CNRS, SIGMA Clermont, Institut de Chimie de Clermont-Ferrand, F63000 Clermont-Ferrand, France; 이이.org/0000-00016250-7550; Email: vanessa.prevot@uca.fr

Christine Mousty - Université Clermont Auvergne, CNRS, SIGMA Clermont, Institut de Chimie de Clermont-Ferrand, F63000 Clermont-Ferrand, France; 이이. ord/0000-00023003-2092; Email: christine.mousty@uca.fr

\section{Authors}

Paulmanickam Koilraj - Université Clermont Auvergne, CNRS, SIGMA Clermont, Institut de Chimie de Clermont-Ferrand, F63000 Clermont-Ferrand, France; 이이. orcid.org/0000-00024643-7772

Masanori Takemoto - Department of Materials Science, Graduate School of Engineering, Osaka Prefecture University, Sakai, Osaka 599-8531, Japan

Yasuaki Tokudome - Department of Materials Science, Graduate School of Engineering, Osaka Prefecture University, Sakai, Osaka 599-8531, Japan; 이이.org/0000-00018644-6385

Angelique Bousquet - Université Clermont Auvergne, CNRS, SIGMA Clermont, Institut de Chimie de Clermont-Ferrand, F63000 Clermont-Ferrand, France 
Complete contact information is available at:

https://pubs.acs.org/10.1021/acsanm.0c01026

\section{Notes}

The authors declare no competing financial interest.

\section{ACKNOWLEDGMENTS}

The authors acknowledge the support received from the Agence Nationale de la Recherche of the French government through the program "Investissements d'Avenir" (16-IDEX0001 CAP 20-25), from CNRS through the joint program PRC No. 2182, and from Japan Society of The Promotion Science (JSPS) bilateral program.

\section{REFERENCES}

(1) Granqvist, C. G. Recent progress in thermochromics and electrochromics: A brief survey. Thin Solid Films 2016, 614, 90-96.

(2) Granqvist, C. G.; Arvizu, M. A.; Bayrak Pehlivan, I.; Qu, H. Y.; Wen, R. T.; Niklasson, G. A. Electrochromic materials and devices for energy efficiency and human comfort in buildings: A critical review. Electrochim. Acta 2018, 259, 1170-1182.

(3) Wu, W.; Wang, M.; Ma, J.; Cao, Y.; Deng, Y. Electrochromic Metal Oxides: Recent Progress and Prospect. Adv. Electron. Mater. 2018, 4 (8), 1800185.

(4) Rani, R. A.; Zoolfakar, A. S.; O’Mullane, A. P.; Austin, M. W.; Kalantar-Zadeh, K. Thin films and nanostructures of niobium pentoxide: fundamental properties, synthesis methods and applications. J. Mater. Chem. A 2014, 2 (38), 15683-15703.

(5) Ding, J.; Zheng, C.; Wang, L.; Lu, C.; Zhang, B.; Chen, Y.; Li, M.; Zhai, G.; Zhuang, X. Viologen-inspired functional materials: synthetic strategies and applications. J. Mater. Chem. A 2019, 7 (41), 23337-23360.

(6) Mortimer, R. J. Electrochromic Polymers. In Encyclopedia of Polymer Science and Technology; Wiley, 2004; pp 1-27; .

(7) Levasseur, D.; Mjejri, I.; Rolland, T.; Rougier, A. Color Tuning by Oxide Addition in PEDOT:PSS-Based Electrochromic Devices. Polymers 2019, 11 (1), 179-191.

(8) Forano, C.; Costantino, U.; Prévot, V.; Gueho, C. T. Chapter 14.1: Layered Double Hydroxides (LDH). In Developments in Clay Science; Bergaya, F., Lagaly, G., Eds.; Elsevier, 2013; Vol. 5, pp 745782.

(9) Taviot-Guého, C.; Prévot, V.; Forano, C.; Renaudin, G.; Mousty, C.; Leroux, F. Tailoring Hybrid Layered Double Hydroxides for the Development of Innovative Applications. Adv. Funct. Mater. 2018, 28 (27), 1703868.

(10) Gu, P.; Zhang, S.; Li, X.; Wang, X.; Wen, T.; Jehan, R.; Alsaedi, A.; Hayat, T.; Wang, X. Recent advances in layered double hydroxidebased nanomaterials for the removal of radionuclides from aqueous solution. Environ. Pollut. 2018, 240, 493-505.

(11) Zubair, M.; Daud, M.; McKay, G.; Shehzad, F.; Al-Harthi, M. A. Recent progress in layered double hydroxides (LDH)-containing hybrids as adsorbents for water remediation. Appl. Clay Sci. 2017, 143, 279-292.

(12) Zhang, G.; Zhang, X.; Meng, Y.; Pan, G.; Ni, Z.; Xia, S. Layered double hydroxides-based photocatalysts and visible-light driven photodegradation of organic pollutants: A review. Chem. Eng. J. 2020, 392, 123684.

(13) Mousty, C.; Prévot, V. Hybrid and biohybrid layered double hydroxides for electrochemical analysis. Anal. Bioanal. Chem. 2013, 405 (11), 3513-3523.

(14) Mahdi, R.; Guérard-Hélaine, C.; Prévot, V.; de Berardinis, V.; Forano, C.; Lemaire, M. Design of Artificial Metabolisms in Layered Nanomaterials for the Enzymatic Synthesis of Phosphorylated Sugars. ChemCatChem 2015, 7 (19), 3110-3115.

(15) Yang, Z.-z.; Wei, J.-j.; Zeng, G.-m.; Zhang, H.-q.; Tan, X.-f.; Ma, C.; Li, X.-c.; Li, Z.-h.; Zhang, C. A review on strategies to LDH-based materials to improve adsorption capacity and photoreduction efficiency for CO2. Coord. Chem. Rev. 2019, 386, 154-182.

(16) Xu, M.; Wei, M. Layered Double Hydroxide-Based Catalysts: Recent Advances in Preparation, Structure, and Applications. Adv. Funct. Mater. 2018, 28 (47), 1802943.

(17) Forano, C.; Bruna, F.; Mousty, C.; Prevot, V. Interactions between Biological Cells and Layered Double Hydroxides: Towards Functional Materials. Chem. Rec. 2018, 18 (7-8), 1150-1166.

(18) Jin, W.; Park, D.-H. Functional Layered Double Hydroxide Nanohybrids for Biomedical Imaging. Nanomaterials 2019, 9 (10), 1404-1425.

(19) Yan, L.; Gonca, S.; Zhu, G.; Zhang, W.; Chen, X. Layered double hydroxide nanostructures and nanocomposites for biomedical applications. J. Mater. Chem. B 2019, 7 (37), 5583-5601.

(20) Lv, L.; Yang, Z.; Chen, K.; Wang, C.; Xiong, Y. 2D Layered Double Hydroxides for Oxygen Evolution Reaction: From Fundamental Design to Application. Adv. Energy Mater. 2019, 9 (17), 1803358.

(21) Li, X.; Du, D.; Zhang, Y.; Xing, W.; Xue, Q.; Yan, Z. Layered double hydroxides toward high-performance supercapacitors. J. Mater. Chem. A 2017, 5 (30), 15460-15485.

(22) Daniel, S.; Thomas, S. 1: Layered double hydroxides: fundamentals to applications. In Layered Double Hydroxide Polymer Nanocomposites; Thomas, S., Daniel, S., Eds.; Woodhead Publishing, 2020; pp 1-76.

(23) Liu, Y.; Gao, Y.; Wang, Q.; Lin, W. The synergistic effect of layered double hydroxides with other flame retardant additives for polymer nanocomposites: a critical review. Dalton Trans. 2018, 47 (42), 14827-14840.

(24) Karami, Z.; Jouyandeh, M.; Ali, J. A.; Ganjali, M. R.; Aghazadeh, M.; Maadani, M.; Rallini, M.; Luzi, F.; Torre, L.; Puglia, D.; Akbari, V.; Saeb, M. R. Cure Index for labeling curing potential of epoxy/LDH nanocomposites: A case study on nitrate anion intercalated Ni-Al-LDH. Prog. Org. Coat. 2019, 136, 105228.

(25) Liu, X.; Zhou, A.; Dou, Y.; Pan, T.; Shao, M.; Han, J.; Wei, M. Ultrafast switching of an electrochromic device based on layered double hydroxide/Prussian blue multilayered films. Nanoscale 2015, 7 (40), 17088-17095.

(26) Zhou, A.; Liu, X.; Dou, Y.; Guan, S.; Han, J.; Wei, M. The fabrication of oriented organic-inorganic ultrathin films with enhanced electrochromic properties. J. Mater. Chem. C 2016, 4 (35), 8284-8290.

(27) Li, Z.; Zhou, Y.; Peng, L.; Yan, D.; Wei, M. A switchable electrochromism and electrochemiluminescence bifunctional sensor based on the electro-triggered isomerization of spiropyran/layered double hydroxides. Chem. Commun. 2017, 53 (63), 8862-8865.

(28) Decher, G. Fuzzy Nanoassemblies: Toward Layered Polymeric Multicomposites. Science 1997, 277 (5330), 1232-1237.

(29) Wang, X.; Li, Y.; Tang, L.; Zhou, W.; Li, S.; Shi, W. A reversible photochromic switch based on self-assembly of layered double hydroxide and decatungstate. Sens. Actuators, B 2016, 223, 634-640.

(30) Brahma, S.; Shivashankar, S. A. Zinc acetylacetonate hydrate adducted with nitrogen donor ligands: Synthesis, spectroscopic characterization, and thermal analysis. J. Mol. Struct. 2015, 1101, 41-49.

(31) Martin, J.; Jack, M.; Hakimian, A.; Vaillancourt, N.; Villemure, G. Electrodeposition of $\mathrm{Ni}$-Al layered double hydroxide thin films having an inversed opal structure: Application as electrochromic coatings. J. Electroanal. Chem. 2016, 780, 217-224.

(32) Mondal, D.; Jack, M.; Villemure, G. Improved contrast between the coloured and transparent states in electrochromic Ni-Al layered double hydroxide films in mixtures of electroactive ions. J. Electroanal. Chem. 2014, 722, 7-14.

(33) Mondal, D.; Villemure, G. Effect of the presence of [Co(bpy) (3) $](2+)$ on the electrochromic responses of films of a redox active Ni-Al-layered double hydroxide. J. Electroanal. Chem. 2009, 628, 6772.

(34) Mondal, D.; Villemure, G. Improved reversibility of color changes in electrochromic $\mathrm{Ni}-\mathrm{Al}$ layered double hydroxide films in 
presence of electroactive anions. J. Electroanal. Chem. 2012, 687, 5863.

(35) Prevot, V.; Tokudome, Y. 3D hierarchical and porous layered double hydroxide structures: an overview of synthesis methods and applications. J. Mater. Sci. 2017, 52 (19), 11229-11250.

(36) Faour, A.; Mousty, C.; Prevot, V.; Devouard, B.; De Roy, A.; Bordet, P.; Elkaim, E.; Taviot-Gueho, C. Correlation among Structure, Microstructure, and Electrochemical Properties of NiAlCO3 Layered Double Hydroxide Thin Films. J. Phys. Chem. C 2012, 116 (29), 15646-15659.

(37) Tokudome, Y.; Morimoto, T.; Tarutani, N.; Vaz, P. D.; Nunes, C. D.; Prevot, V.; Stenning, G. B. G.; Takahashi, M. Layered Double Hydroxide Nanoclusters: Aqueous, Concentrated, Stable, and Catalytically Active Colloids toward Green Chemistry. ACS Nano 2016, 10 (5), 5550-5559.

(38) Oestreicher, V.; Fábregas, I.; Jobbágy, M. One-Pot EpoxideDriven Synthesis of $\mathrm{M} 2 \mathrm{Al}(\mathrm{OH}) 6 \mathrm{Cl} \cdot 1.5 \mathrm{H} 2 \mathrm{O}$ Layered Double Hydroxides: Precipitation Mechanism and Relative Stabilities. J. Phys. Chem. C 2014, 118 (51), 30274-30281.

(39) Oestreicher, V.; Jobbágy, M. One Pot Synthesis of Mg2Al$(\mathrm{OH}) 6 \mathrm{Cl} \cdot 1.5 \mathrm{H} 2 \mathrm{O}$ Layered Double Hydroxides: The Epoxide Route. Langmuir 2013, 29, 12104.

(40) Vialat, P.; Leroux, F.; Taviot-Gueho, C.; Villemure, G.; Mousty, C. Insights into the electrochemistry of $(\mathrm{CoxNi}(1-\mathrm{x})) 2 \mathrm{Al}-\mathrm{NO} 3$ Layered Double Hydroxides. Electrochim. Acta 2013, 107 (0), 599610.

(41) Taviot-Gueho, C.; Vialat, P.; Leroux, F.; Razzaghi, F.; Perrot, H.; Sel, O.; Jensen, N. D.; Nielsen, U. G.; Peulon, S.; Elkaim, E.; Mousty, C. Dynamic Characterization of Inter- and Intralamellar Domains of Cobalt-Based Layered Double Hydroxides upon Electrochemical Oxidation. Chem. Mater. 2016, 28 (21), 7793-7806. (42) Shi, J.; Lai, L.; Zhang, P.; Li, H.; Qin, Y.; Gao, Y.; Luo, L.; Lu, J. Aluminum doped nickel oxide thin film with improved electrochromic performance from layered double hydroxides precursor in situ pyrolytic route. J. Solid State Chem. 2016, 241, 1-8.

(43) Carpenter, M. K.; Conell, R. S.; Corrigan, D. A. The electrochromic properties of hydrous nickel oxide. Sol. Energy Mater. 1987, 16 (4), 333-346.

(44) Chen, Z.; Xiao, A.; Chen, Y.; Zuo, C.; Zhou, S.; Li, L. Highly porous nickel oxide thin films prepared by a hydrothermal synthesis method for electrochromic application. J. Phys. Chem. Solids 2013, 74 (11), 1522-1526.

(45) Prevot, V.; Forano, C.; Besse, J. P. Hydrolysis in Polyol: New Route for Hybrid-Layered Double Hydroxides Preparation. Chem. Mater. 2005, 17 (26), 6695-6701.

(46) Leont'eva, N. N.; Cherepanova, S. V.; Drozdov, V. A. Thermal decomposition of layered double hydroxides $\mathrm{Mg}-\mathrm{Al}, \mathrm{Ni}-\mathrm{Al}, \mathrm{Mg}-\mathrm{Ga}$ : Structural features of hydroxide, dehydrated, and oxide phases. $J$. Struct. Chem. 2014, 55 (7), 1326-1341.

(47) Géraud, E.; Rafqah, S.; Sarakha, M.; Forano, C.; Prevot, V.; Leroux, F. Three Dimensionally Ordered Macroporous Layered Double Hydroxides: Preparation by Templated Impregnation/ Coprecipitation and Pattern Stability upon Calcination. Chem. Mater. 2008, 20 (3), 1116-1125.

(48) Stein, A.; Li, F.; Denny, N. R. Morphological Control in Colloidal Crystal Templating of Inverse Opals, Hierarchical Structures, and Shaped Particles. Chem. Mater. 2008, 20 (3), 649666. 